\title{
LETRAMIENTO Y MESTIZAJE EN EL NUEVO REINO DE GRANADA, SIGLOS XVI Y XVII
}

\author{
LITERACY AND MESTIZAJE IN THE NUEVO REINO DE GRANADA, \\ SIXTEENTH AND SEVENTEENTH CENTURIES
}

\author{
Joanne Rappaport*
}

\begin{abstract}
El acto de clasificación sociorracial y la atribución de la calidad de indio, mestizo, negro o español a un individuo era una performance mediada por la alfabetización (el letramiento) en la Colonia temprana. Este artículo analiza la escritura como un conjunto de prácticas y relaciones sociales que, mediante su desenvolvimiento en el espacio social, categorizaba a los habitantes del Nuevo Reino de Granada (hoy, Colombia). Por lo tanto, se entiende el letramiento como un proceso social y no exclusivamente como una técnica; por igual, se entiende la clasificación sociorracial como un acto situado en una relación social e institucional y en un contexto burocráctico-legal.
\end{abstract}

Palabras claves: letramiento, alfabetización, visualidad, papelrealidad, muisca, mestizo, Nuevo Reino de Granada.

In the early colonial period, the act of racial classification and the attribution of the "calidad" of indio, mestizo, black, or Spaniard to individuals was a performance mediated by literacy. This article analyzes writing as a bundle of practices and social relationships that, as it unfolded in social space, classified the inhabitants of the New Kingdom of Granada (today, Colombia). Consequently, literacy is understood as a social process and not only a technology; correspondingly, socio-racial classification is understood as a socially and institutionally situated act taking place in a bureaucratic and legal context.

Key Words: literacy, writing, visuality, paperreality, Muisca, mestizo, New Kingdom of Granada.

\section{Introducción}

Imagine una escena de principios del siglo XVI: Un oficial español está frente a un grupo de caciques muiscas, tributarios indígenas y sus familias en el pueblo de indios de Sogamoso (Figura 1), unos 200 kilómetros al nordeste de la ciudad de Santafé (hoy Bogotá). Están en la plaza del pueblo, frente a la iglesia, donde un oficial de la Corona lee en voz alta una real cédula que ordena la inspección -una visita- de las comunidades indígenas de la región, con el objetivo de precisar el número de tributarios en cada pueblo, así como su capacidad de proveer suficiente tributo a la Corona. El oficial llega al final del decreto, donde el escudo del rey hecho en sello de lacre se presiona sobre el material del documento. Mira el sello real, lo besa y lo pone sobre su cabeza en un acto que expresa su voluntad de obedecer el contenido del documento. Un escribano, que está sentado en una mesa cercana, registra esta acción, incluyendo el beso al sello real, en un lenguaje formulaico que varía muy poco entre documentos, desde el siglo XVI al XVIII.

Semanas después, la plaza se llena nuevamente de una muchedumbre de espectadores. Los caciques de Sogamoso han reunido a sus súbditos, que esperan en una larga fila para ser examinados por los oficiales encargados de recopilar la lista de tributarios en cada uno de los pueblos de la jurisdicción de Sogamoso y de conducir una investigación exhaustiva sobre las prácticas de evangelización y los abusos contra los tributarios nativos. En una mesa está sentado el visitador -el magistrado encargado de conducir la inspecciónrodeado de soldados. El cura doctrinal está de pie detrás, notarios y sus secretarios están de pie a su lado, ocupados intentando escribir los, en ocasiones intranscribibles, nombres muiscas que les ha transmitido el intérprete (muy probablemente un mestizo local o "un indio ladino", hablante de español), quien, arrogantemente, examina la interminable fila de hombres muiscas, a quienes

\footnotetext{
* Georgetown University, Departamento de Español y Portugués, Georgetown, Estados Unidos. Correo electrónico: rappapoj@georgetown.edu

Traducción de Verónica Zacipa. Georgetown University, Georgetown, Estados Unidos de América.
} 


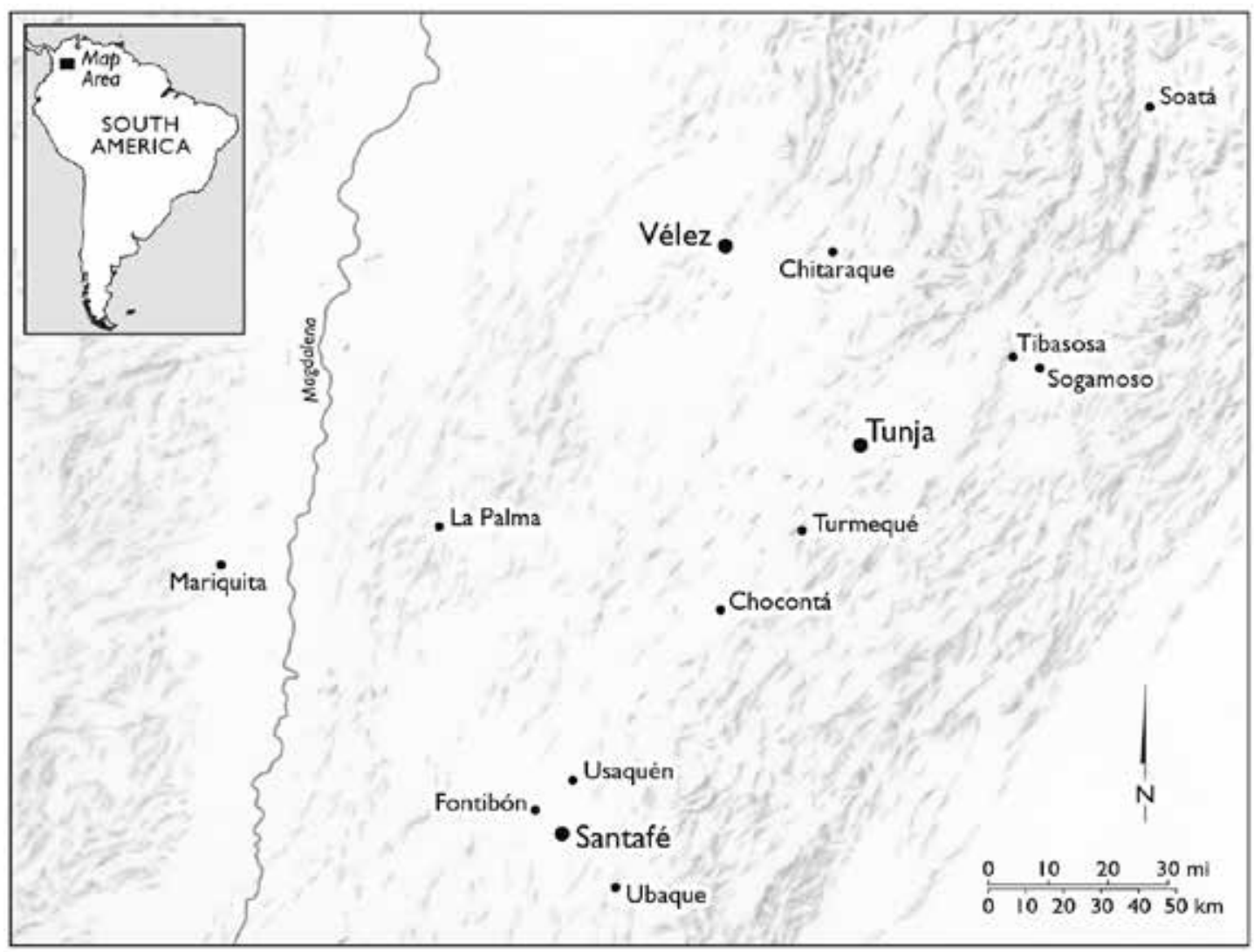

Figura 1. Mapa de las Provincias de Santafé, Tunja y Vélez.

ve como inferiores socialmente. Los funcionarios reunidos intentan dar sentido a lo que distingue a un tributario indígena del otro, aunque el ojo fisiognómico del europeo colonial, con su insistencia en anotar la presencia o ausencia de barbas y su limitada paleta de colores de la piel, no podía dar cuenta de la variedad de típicos físicos indígenas que veía (Rappaport, 2012). Imaginemos que nuestro magistrado imaginario es tan cuidadoso como lo era el visitador que hizo el censo de los tributarios en los pueblos de Cucunubá y Simijaca en 1568: describió a don Hernando, el cacique de Bogotá, como un "yndio ladigno y cristiano... alto de cuerpo barbado en el boço" ". Cada uno de los súbditos del cacique debe responder las preguntas del magistrado por medio de un intérprete. Después, el escribano registra si quien responde habla español (es decir, si es ladino) o únicamente la lengua muisca (si es chontal); su descripción física y si ha sido bautizado; los nombres y edades de los miembros de su familia. Todos estos datos son atestiguados atentamente por el notario, quien validará el documento final con las palabras "ante mí’, su firma y su rúbrica.

El documento definitivo de la visita reproduce la larga línea de tributarios y sus familias: primero, el cacique de Sogamoso, su familia y sus criados; luego, los hombres tributarios que dependen de él, seguidos por los reservados -hombres de más de cincuenta años exentos del pago de tributo- $y$, finalmente, las mujeres solteras y los niños -frecuentemente agrupados bajo las categorías "solteras" y "chusma" (algunos de los cuales son mestizos o mulatos, estos últimos, los hijos de uniones entre indígenas y negros) (Guevara-Gil y Salomon 1994). En efecto, la performance burocrática de la visita crea una jerarquía social instantánea que corresponde a la plantilla europea, que privilegia los nobles sobre los plebeyos, los hombres sobre las mujeres, adultos trabajadores sobre niños y adultos mayores, categorías "puras" sobre categorías mezcladas. El mismo proceso se repite con los mandatarios indígenas menores, llamados capitanes, cada uno de los cuales tiene su cuerpo de tributarios. 


\section{Letramiento como práctica}

Como Tom Cummins y yo explicamos en Beyond the Lettered City, la documentación de los procedimientos de mi visita imaginaria no pueden entenderse simplemente como los registros escritos de un procedimiento burocrático. En cambio, se debe entender como el rastro de una serie de prácticas que se intersectan: la oralidad de la lectura del decreto hecha por el oficial y su naturaleza formulaica; el ritual por medio del cual el magistrado promulga su obediencia al orden real; el objeto visual y táctil que es el sello real, que el magistrado besa; la procesión de caciques y tributarios que se presentan a las autoridades para dar testimonio y registrar sus nombres; las descripciones físicas de cada tributario (estas desaparecen en visitas posteriores) y su clasificación según género, edad y categoría sociorracial (en el español de la época, su "calidad"); y, finalmente, la composición gráfica del documento de la visita, que parece una línea de tributarios encabezada por sus caciques, con las mujeres y los niños de razas mezcladas al final. Esta serie de prácticas que constituyen la visita es lo que llamo "letramiento" (literacy). Claramente, trasciende la escritura alfabética de múltiples maneras ${ }^{2}$.

La misma visita también debe ser considerada en términos de la eficacia de la serie de prácticas que la componen. Como argumenta Matthew Hull, documentos como este unen grupos de personas en alianzas situacionales, como, por ejemplo, el grupo de caciques y sus capitanes que actúan como una unidad en respuesta a las órdenes de la Corona (Hull 2012). En el curso de la inspección, estos señores nativos son forzados a posicionarse y reposicionarse de acuerdo con su rango en la jerarquía nativa, que en el siglo XVI ha sido reestructurada debido a la disminución de la población y la menguante influencia de caciques regionales, como el señor de Sogamoso (Herrera 2002). Estos actúan como grupo para asegurar que el registro de los tributarios no esté lleno de nombres de personas que han muerto o desaparecido de la comunidad. Además, cuidadosamente seleccionan testigos que confirmen su propio testimonio sobre las deficiencias del encomendero. Parte de la efectividad de la visita reside, por tanto, en su capacidad de movilizar grupos hacia un objetivo común.

Sin embargo, el documento en sí, la serie de folios que registran los procedimientos de la visita, seguidos por las recomendaciones finales del visitador, también es efectivo en tanto registro escrito. La noción de papelrealidad (papereality), acuñada por David Dery, nos ayuda a comprender cómo la visita logra algo más que representar en el papel el mundo "por ahí" de Sogamoso colonial. Según Dery, la escritura burocrática -la visita es solo uno de los muchos géneros de escritura administrativa del período colonial- constituye una realidad legal: en la práctica administrativa construye y privilegia cierta visión de mundo y estado de cosas. En palabras de Dery, una vez se ha compilado, el documento burocrático "se convierte en el mundo" (Dery 1998). Para continuar con la idea de letramiento como el nexo entre una serie de prácticas, considero que, en el caso de la visita, la particular combinación de palabras escritas, la aceptación ritual del documento por las autoridades mencionadas que actúan según una serie de fórmulas concretas, la celebración pública de relaciones sociales y jerárquicas por grandes grupos de personas, la forma en que la visita constituye unidades sociales y cómo clasifica las personas: todas estas prácticas hacen de esta inspección mucho más que solo palabras registradas en hojas de papel. En cambio, constituyen una herramienta para rehacer el mundo indígena según una imagen colonial. Por tanto, no es solo la escritura en sí misma, sino una constelación de prácticas relacionadas, lo que le confiere eficacia a la visita.

\section{Clasificaciones fluidas}

En este artículo me enfocaré en el proceso por medio del cual se clasifican las personas, que observamos en la parte de la visita durante la cual se enumera la población indígena: los hombres tributarios encabezados por sus caciques; los reservados, hombres exentos del pago de tributo debido a su edad avanzada o a enfermedad; las esposas y los hijos, que se distinguen de los hombres por su estatus de no tributarios; mujeres solteras y sus hijos, que son insertados al final del censo. El trazo de una pluma los identifica como caciques o comuneros; como indios, mestizos o mulatos; como hombres, mujeres o niños; como tributarios o aquellos exentos de pagar tributo a la Corona. Tales clasificaciones se convirtieron en ataduras legales en el curso del ritual de la visita y su inscripción en la página escrita, debidamente atestiguada y firmada por un notario. La calidad, o clasificación sociorracial -un término conveniente, por ahora, para la asignación 
de individuos al grupo de "indios" o "mestizos", pero que desarrollaré más adelante-, no siempre fue una realidad preexistente antes de la puesta en escena y composición de la visita. Por el contrario, la clasificación de una persona como indio o mestizo, como cacique o comunero, como tributario o reservado, emergió de un contexto legal específico, un momento de inscripción válido jurídicamente, una performance que podemos entender como un escenario etnográfico susceptible de analizar como una serie de interacciones sociales. Esto es apropiado tanto para las visitas como para otros géneros de documentación colonial, ya que todos los documentos coloniales eran actos cuya eficacia dependía de la puesta en escena del letramiento.

Mediante el ejercicio de la papelrealidad, un individuo podía lograr un estatus particular en la esfera legal. De hecho, por lo general, mucho antes de la llegada de un visitador, los caciques ejercían el poder en sus comunidades en virtud de un nombramiento oficial por el Rey -otro ejemplo de la papelrealidad-. La mayoría de los muiscas que vivían en pueblos eran considerados "indios" antes del momento en que eran registrados como tributarios durante la visita. Pero el momento de la inscripción en el registro de la inspección transformaba sus realidades vividas en verdades jurídicas, que les confería el derecho a vivir en el pueblo y los obligaba a pagar tributo a la Corona. Quizás, en otros papeles los mismos señores no eran identificados como caciques; posiblemente, los mismos indios ya habían sido registrados en otras visitas como súbditos de otros caciques. El ejercicio de la papelrealidad reconciliaba estos conflictos, los alineaba con los intereses del momento: por encima de todo, los intereses de funcionarios de la Corona, pero también los de caciques y capitanes, quienes coordinaban la presentación de los datos al visitador.

Algunas de las fórmulas de clasificación colonial eran relativamente transparentes, para que la papelrealidad y la realidad vivida coincidieran: todos los tributarios hombres que encontré en los registros parecen haber vivido vidas generizadas como hombres antes de la llegada del visitador; muchos -por supuesto, no todos-de los tributarios muiscas nunca salieron de sus lugares de nacimiento por períodos extendidos, así que era obvio a qué comunidad pertenecían; había caciques cuyo estatus de nobleza no se cuestionaba y eran, por tanto, reconocidos sin problema alguno como señores por herencia ${ }^{3}$. Pero la clasificación sociorracial-la atribución de calidad- era notablemente más resbaladiza, con individuos en constante movimiento entre una y otra categoría. No siempre era sencillo identificar quién era un "mestizo" y quién un "español". El proceso de identificación no estaba basado en la apariencia física de una persona, como podría suponer un lector del siglo XXI. En distintas etapas de su vida o en contextos documentales diferentes, las personas podían adquirir clasificaciones diversas o podrían disputar la categoría que les había sido asignada.

Es más, es imposible determinar a qué categoría pertenecía un individuo "en realidad", pues esto implica asumir que tales clasificaciones eran estables y fijas. En cambio, debemos observar cómo los procesos coloniales de identificación cambiaban, según las circunstancias y relaciones de poder. En los siglos XVI y XVII, la base epistemológica de una diferenciación racial giraba alrededor de la mutabilidad de las características externas, bastante opuesto a la estabilidad de las nociones modernas de raza (bien sea en Norteamérica o en América Latina). Solamente en el siglo XIX el cuerpo empezó a ser reconocido como un objeto medible y transparente, una constante resistente al tiempo variable, que hizo posible el surgimiento de lo que llegó a ser visto como un sistema estable de clasificación racial ${ }^{4}$. Por tanto, no podemos asumir que los pobladores coloniales estaban tratando de ocultar algo cuando sus atributos de calidad cambiaban, por ejemplo, de "indio" a "mestizo" o de "mestiza" a "española". Tampoco debemos asumir que las clasificaciones siempre estaban en el color de piel, debido a que los observadores de la modernidad temprana eran notoriamente ambiguos en el uso de términos sobre el color (Groebner 2007). Lo importante era el momento en el cual una ficción legal se validaba legalmente por medio de una puesta en escena y la escritura pública. Ese era el momento en que una clasificación se volvía eficaz -si se quiere, "verdadera"-. Tal vez sea más sugerente explorar el caso de los mestizos para explicar mejor este tema.

\section{¿Quiénes Eran Mestizos?}

Es común entre aquellos que no están familiarizados con la América española colonial imaginar la fábrica sociorracial del mundo del siglo XVI según los cuadros de castas mexicanos del siglo XVIII: una ordenada progresión de representaciones de los diferentes grados de mezcla (las diferentes “castas") representadas por los retratos de parejas 
con sus hijos, cada categoría con su propia etiqueta y sus características pictóricas organizadas sistemáticamente en una red anclada en las principales clases de "indio", "español" y "negro" (Carrera 2003; Katzew 2004). Sin embargo, "casta" no era un término utilizado en la América española durante el siglo XVI para denotar grupos sociorraciales delimitados. En cambio, la clasificación según calidad era todo excepto sistemática: en la época colonial había una marcada movilidad en el acto de clasificar a alguien (Rappaport 2014) ${ }^{6}$.

Puede ser mejor empezar por explicar qué significaba "mestizo" en la Colonia temprana, pues los significados asociados con este término incorporan todas las inconsistencias y ambigüedades que he mencionado. "Mestizo" es, probablemente, una de las categorías más impenetrables en los registros documentales de la América española colonial. Sebastián de Covarrubias le dedica una sola oración al "mestizo": "el que es engendrado de diversas especies" (Covarrubias 1995 [1611]). Esta excesivamente escueta definición no menciona en absoluto la categoría sociorracial; solo alude a la noción general de mezcla ${ }^{7}$. En contraste, "indio" y "español” eran mucho más específicos, funcionaban como categorías adscriptivas y como términos generales para grupos con derechos y obligaciones determinados. Los españoles, por ejemplo, disfrutaban el derecho a cierto tipo de ciudadanía, como el estatus de "vecino" que les permitía ocupar cargos públicos (Herzog 2003). Se les permitía usar cierto tipo de vestimenta y de joyas, como capas y perlas. A su vez, se requería su participación en variados rituales públicos durante el año, promulgaciones ceremoniales que tanto representaban como mantenían las nociones cristianas de jerarquía. Del mismo modo, "indio" era una categoría adscriptiva que abarcaba los grupos socialmente identificables como aborígenes que estaban obligados a pagar tributo a la Corona, pero estaban exentos de las jurisdicciones de otras instituciones coloniales, como la Inquisición. Incluso si escapaban de sus obligaciones tributarias y buscaban el anonimato en Santafé o la vecina ciudad de Tunja, los indios seguían unidos, al menos marginalmente, a una colectividad, a los ojos de las autoridades coloniales. Ellos también "desempeñaban" su estatus de indios en la esfera judicial, donde asumían la etiqueta de "indio" como un vehículo para reclamar los derechos asociados con su categoría legal ${ }^{8}$. Tanto españoles como indios también pertenecían a grupos más concretos en la práctica: los españoles eran vascos, castellanos o catalanes, y se distinguían, según su lugar de nacimiento, como naturales (nativos) de Sevilla, Toledo o Carmona ${ }^{9}$. Los indios se identificaban como miembros de pueblos específicos, distinguidos por su ubicación: los sogamosos, por ejemplo, vivían bajo la autoridad del cacique de Sogamoso (Baber 2009).

Sin embargo, "indio" y "español" eran categorías que no eran totalmente estables u homogéneas, y sus límites no eran fijos o estaban delimitados claramente. Por tal razón, es más útil pensar que exhiben características de "grupalidad" que referirse a ellos en el sentido sociológico de la palabra (Brubaker y Cooper 1998). Esto es, que recurrieron a algunas clases de concordancia que llevaron a la gente a adoptar actitudes similares, a asociarse unos con otros, a compartir una definición explícita de quiénes eran y quiénes no pertenecían a su grupo. Pero aun así, la porosidad de sus límites hizo que estos ensamblajes de individuos fueran altamente heterogéneos; mulatos y mestizos podían ser clasificados como "indios"; a las mestizas de élite se les refería frecuentemente como "españolas" (mientras que a los mestizos de élite no) (Rappaport 2012). Sin embargo, las desviaciones eran más difíciles de percibir para estas categorías aparentemente "puras" que para la categoría de mestizo, cuya falta de cohesión fácilmente permitía a la gente salir y entrar en ella.

Aquellos asignados a la categoría mixta de "mestizo" son solo a veces aparentes en los registros documentales; solamente en ocasiones son identificados por su linaje en los documentos. Podían ser llamados "mestizos" en un momento e "indio" o "español" en otro, algunas veces por el mismo testigo. En efecto, "mestizo" denota una relación particular con el observador, más que reflejar las cualidades de un individuo (de igual manera, por supuesto, sucede con "indio" y "español", aunque no es tan obvio). La fluidez de la etiqueta "mestizo" surge de la ausencia de un grupo sociológico de mestizos al cual pertenecer: es simplemente una categoría a la que eran asignados ${ }^{10}$. Los mestizos no tenían obligaciones específicas con una colectividad, como era el caso de indios y españoles, ni les era requerido, como grupo, pagar cierto tipo de impuestos, como era el caso de los mulatos; no estaban sujetos a pagar tributo, como los indios, ni a la esclavitud, como los esclavos africanos y afrodescendientes. Más aún, el rango de personas 
que podían ser asignadas al grupo de mestizos era amplio y difuso: los hijos ilegítimos y no reconocidos de españoles con mujeres nativas, que se mezclaban entre la población indígena; los habitantes de los barrios plebeyos de Santafé y Tunja, quienes, al parecer, aceptaron su designación como mestizos sin más problemas; los hijos mestizos de los españoles de élite, quienes vivían en el corazón de la sociedad urbana refinada y muchas veces se deslizaban entre los pliegues españoles. Para citar a Stuart Schwartz y Frank Salomon (1999: 444): "las personas de nacimiento mixto formaban, no tanto una categoría, sino un desafío a la categorización misma".

Más aun, "mestizo" frecuentemente reemplazaba algo más: cumplía el rol de un significado vacío. Tal cualidad se puede observar en las páginas del texto peruano del siglo XVII, El primer nueva corónica y buen gobierno, cuyo autor, Felipe Guaman Poma de Ayala, cuenta que al casarse un cacique con una india plebeya, sus descendientes se convertían en mestizos (1980: 788 [1615: 802]). Nótese que la mezcla etiquetada por el cronista indígena peruano se informa entre dos clases de personas nativas, no entre miembros de categorías sociorraciales distintas. La púa que Guamán Poma hace a los caciques desordenados ilustra que la noción de mezcla no se centraba exclusivamente en uniones interétnicas, sino que se volcaban generalmente hacia la cuestión del estatus. La jerarquía social ibérica -de hecho, las jerarquías sociales de muchos países de Europa, incluyendo Francia e Inglaterra- estaba fundada en la promoción y el mantenimiento de linajes nobles y en asegurar la pureza de la sangre noble que fluía de generación en generación (Feerick 2010). Todo esto se lograba por medio de la supervisión de uniones, así como de los plebeyos o herejes condenados y de los conversos, quienes eran vistos como una amenaza a la integridad de las líneas familiares nobles. La noción francesa de mésalliance ("casamiento desigual" con alguien inferior socialmente) cristaliza el problema de la mezcla, aludido por Guaman Poma. Nos dirige lejos de la idea de "raza" como la conocemos hoy en día y hacia una noción moderna temprana de jerarquía en la que "raza" significaba "linaje" (Covarrubias 1995: 282 [1611]). De acuerdo con esta muy diferente apreciación del significado de "raza", los hijos de los casamientos desiguales franceses eran llamados "métis", término francés para "mestizo" (Aubert 2004: 445-448).

Por tanto, "mestizo" era una etiqueta que se aplicaba a múltiples actores por parte de los observadores coloniales, así como una etiqueta autoatribuida. No podemos estar seguros de que un individuo que, en una declaración documental particular, sea llamado "mestizo" vaya a llevar esta clasificación durante toda su vida, o que "mestizo" haya significado lo mismo para él y sus vecinos que para el notario que testificó la firma de su testamento, o para el sacerdote local que bautizó a sus hijos. En otras palabras, no podemos asegurar que "mestizo" representara unas características permanentes de su propio ser: ciertamente, no era algo que un observador pudiera identificar fácilmente de vista. La cuestión central ante nosotros, entonces, no es "¿Quién es un mestizo?” o “¿Qué es un mestizo?”, sino “¿Cuándo y dónde es mestiza una persona?". Esto es, debemos cambiar nuestra mirada de la condición del individuo hacia el contexto del nombramiento. Aquí, una vez más, la papelrealidad entra en juego.

\section{Visualizando y contando mestizos}

Considere un cuadro pintado en 1656 por Gaspar de Figueroa: la misa de San Nicolás de Tolentino y las almas del Purgatorio, colgado en la iglesia de Cómbita, al suroeste de Sogamoso. La pintura inserta una serie de actores locales en la representación de un milagro europeo ${ }^{11}$. Nótese en el centro de la imagen un niño vestido con traje muisca, el hijo del cacique local, don Pedro Tabaco. La pintura fue donada a la iglesia por la cofradía local, de las almas del Purgatorio, y el cacique fue quien hizo la donación más generosa. Posiblemente, el cacique es el hombre de bigote en el lado derecho, o tal vez el hombre de barba, rodeado de negro, en la esquina inferior izquierda. Ninguno parece ataviado con traje indígena (como el niño), puesto que los caciques, por costumbre, usaban trajes españoles, como lo ilustra la imagen del cacique de Sutatausa (al sur de Cómbita), datada hacia $1620^{12}$. También es posible que la figura ubicada a la izquierda sea un mestizo ${ }^{13}$; hay evidencia que sugiere que los mestizos locales jugaron un papel importante en las fraternidades religiosas, como la que patrocinó esta pintura.

Es difícil identificar a los mestizos en las imágenes coloniales, así como era un reto para los oficiales españoles identificar quién era un mestizo o un mulato para los objetivos de la visita. ¿Cómo "se veía" un indio o un mestizo? Don Juan, el cacique de Cunucubá, un pueblo de indios cerca del centro colonial urbano de Vélez, fue (tal vez falsamente) 
acusado de ser mestizo en un esfuerzo por destituirlo de su cargo. Como evidencia, se suministró una descripción de su aspecto: "A este testigo le pareze que el dicho don Juan es mestiço porque tiene la color de otra manera que los yndios"14. A lo que se refiere exactamente con "la color de otra manera" no se explica en ninguna parte del documento. Esta imprecisión es significativa: sugiere que los mestizos no podían ser categorizados según el color tan fácilmente, o que, tal vez, don Juan no era mestizo en absoluto, y sus detractores luchaban por encontrar una manera de clasificarlo como tal. Padre Gonzalo García Zorro, mestizo y director de coro de la Catedral de Santafé es descrito en sus documentos de viaje como "de mediana estatura moreno de rostro barb[i]negro que le apuntan" -esta terminología de color y la descripción de su barba era común a las descripciones físicas en los documentos de viaje de los españoles, así como para los mestizos, lo que sugiere una escasez de términos acerca del color para referirse a los no europeos ${ }^{15}$.

En cualquier caso, las diferencias de color y linaje frecuentemente se borraban en las visitas, durante las cuales las autoatribuciones se ignoraban con el interés de registrar más tributarios. La inspección de Chocontá de 1639 (al suroeste de Sogamoso, más cerca de la sede de la Real Audiencia en Santafé) tenía como intención, en parte, de erradicar a los no nativos, cuya presencia en el pueblo se veía como un estorbo para la cristianización de los habitantes indígenas y como una forma de exponerlos al engaño, el robo y el fraude. Un mulato libre de sesenta y tres años, llamado Lázaro, fue identificado como residente ilegal, aunque había vivido en la comunidad durante toda su vida. Lázaro era hijo y nieto de mujeres nativas; su esposa también era indígena. Se identificaba a sí mismo como "de color mulato", pero también reclamaba ser "natural" de Chocontá ${ }^{16}$. "Natural" era un término utilizado para referirse a personas indígenas, pero también era usado para hablar sobre el origen de cualquier persona, tal como "natural" de Sevilla; es probable que la comprensión de Lázaro sobre sí mismo como "natural" se sobreponía incómodamente con la del visitador. En los registros de la visita, los hijos de Lázaro fueron inscritos como indios tributarios, a pesar de que su padre fuera un mulato. Seis años más tarde, Juana Galván, la hija mestiza de un español que tenía una encomienda en el pueblo de Chitaraque, al norte de la ciudad de Vélez, pidió ser retirada de los registros de tributos por cuanto era la hija de un español; ella aducía que el visitador, maliciosamente, la había clasificado como india, y así había expuesto a su hijo -que era producto de su unión con un sacerdote español- a la amenaza del cobro de tributo, como si fuera un indio ${ }^{17}$.

La designación de Juana Galván o de los hijos de Lázaro Mulato con la etiqueta de "indio" es un ejemplo de la papelrealidad, el proceso burocrático por medio del cual las clasificaciones raciales en el papel se convertían en realidades sociales con las cuales los individuos debían vivir para bien (como en el caso de los hijos de Lázaro) o para mal (como en la queja de Juana Galván). Ser clasificado como mestizo o mulato, como español o indio, implicaba una diferencia en la vida, porque la clasificación determinaba los derechos y obligaciones en la sociedad colonial. Se puede decir que el sistema legal de la colonia española convirtió la escritura en fetiche -en Ceremonies of Possession, Patricia Seed sostiene que la alfabetización letrada occidental fue el vehículo por el que los españoles buscaban reclamar las Américas. Bajo tales circunstancias, el acto de apuntar la calidad de una persona era más que un simple acto de registro: era una forma de ingeniería social mediante una performance pública.

Bhavani Rahman (2012: 3) anota que "la papelrealidad hace invisible el artificio de escribir". En el caso del Nuevo Reino de Granada, añadiría que la papelrealidad hacía invisible el artificio de la clasificación racial: cada documento parece prestar una permanencia a un acto de clasificación que no necesariamente reflejaba el aspecto o el parentesco de una persona. En el flujo de la vida social estas formas de clasificación eran situacionales; estaban distribuidas en el curso de diálogos adversos. Esto es, eran constructos sociales que no eran evidentes en absoluto. Los registros de disputas legales o de procesos administrativos asignaban a los individuos una u otra categoría, en un proceso atravesado por el poder: esto es claro en el ejemplo de Juana Galván, cuya calidad fue decidida por el magistrado que la registró como india, para satisfacer los intereses del encomendero. Las clasificaciones raciales de la era colonial pueden ser pensadas como un artificio, una ficción legal: los magistrados y notarios no necesariamente estaban haciendo visible algo que ya existía, sino que, en cambio, estaban tramando los contornos de las relaciones sociales dentro de contextos legales claramente delimitados. El artificio de la clasificación racial emergía de actos de habla inscritos dentro de documentos, en los 
cuales los individuos eran identificados por los observadores o por sí mismos como pertenecientes a una categoría particular, y ciertas identificaciones eran privilegiadas por encima de otras. Asociados cercanos de estatus similar podían identificar un individuo de forma diferente de lo que lo haría un oficial colonial (Boyer 1998). Pero, al final, el oficial colonial tenía la última palabra.

\section{El Desnarigado}

Un caso ocurrido en Fontibón a mediados del siglo XVII ilustra este punto convincentemente. Concierne a un zapatero, Juan de Salazar, quien estaba en prisión en 1650 por haber arrancado la nariz de un mordisco a Juan de Medina, un curtidor de oficio ${ }^{18}$. Supuestamente, Salazar desfiguró a Medina en una riña fuera de la casa del cacique de Fontibón, un pueblo indígena cerca de Santafé. La pelea entre Juan de Medina y Juan de Salazar estalló cuando, en medio de una fiesta organizada por el cacique, ambos hombres, presumiblemente, habían tomado su ración de chicha. Un diverso grupo atendió la fiesta -indios, mestizos y probablemente mulatos-. También había caciques y gobernadores indígenas de comunidades vecinas en la celebración, así como una gama de artesanos -curtidores, zapateros, barberos y pintores-, una fiesta cuyos invitados eran tan diversos como lo era la vecina Santafé (124-147).

En la documentación, Juan de Medina se identifica como "indio", mientras que la adscripción de Juan de Salazar fluctúa durante el curso del caso criminal en su contra. Al principio se le clasifica como "mestizo", pero más tarde es llamado "indio" por parte de ciertos actores y "mestizo" por parte de otros. Las circunstancias de este movimiento de una designación intermedia hacia lo que se podría llamar una categoría "pura", así como las discrepancias entre la manera en que Salazar es identificado por sus pares, en oposición a la de sus superiores, nos presenta un caso arquetípico de cómo se navegaba en la categoría de "mestizo" en el período colonial.

Como en todos los casos criminales, el primer detalle en el procedimiento en contra de Juan de Salazar es una descripción de su ataque contra Juan de Medina, narrado por un testigo, en este caso, un indio ladino, un indígena hispanohablante. Francisco de Ortega, un pintor, describe gráficamente la pelea, y embellece su narración con citas directas:
Ayer noche como a las nueve della pasando este testigo por la puerta de la cassa de don Juan cacique de Hontiuon oyo que estaban adentro baylando y entro a ver y boluiendo a salir vio salir de la dicha cassa a Juan de Salazar y a este tiempo estaua a la puerta de la dicha cassa Juan de Medina yndio el qual dixo a el dicho Salazar que ay yaya porque le llaman asi y el dicho Juan de Salazar dixo al dicho yndio a puerco y el dicho yndio le replico mas puerco sois vos y con esto el dicho Juan de Salazar asio al dicho yndio y dio con el en el suelo y estando sobre el vio este testigo que con las dientes le coxio de las narizes y le arranco vn pedazo de ellas de que le salio al dicho yndio mucha sangre y esto vio este testigo como estaua la noche clara con luna (125v).

Se dice que Salazar le arrancó de un mordisco la nariz a Medina. El verbo usado en el documento es "desnarigar" un terrible acto aún más sorprendente por el comentario, relativamente nimio, que lo provocó -un apodo- así como por la copiosa cantidad de sangre que, según se dice, se derramó de la nariz del curtidor.

Tan pronto como fueron informadas de la ofensa, las autoridades corrieron a la zapatería de Salazar, donde lo encontraron rodeado de sus herramientas de trabajo, que confiscaron. El zapatero fue obligado a confesar. Dijo que tenía veinticinco años, que era nativo de Quito y casado con Isabel India. Añadió que Medina era su amigo y reconoció que la riña fue ocasionada porque el curtidor le llamó con el apodo familiar "Yaya"19. Pero que había sido una pequeña escaramuza, Salazar afirmaba: "le quito un pedaço miu pequeño dellas" (127v).

Un investigador visitó a Medina, quien estaba recluido en sus habitaciones de enfermo, para comprobar la extensión de sus heridas: "Auiendo entrado en vn aposento della hallamos al sussodicho hechado en vna cama y le hiçe descubrir vnas bendas y parches que tenia puestos en las nariçes y en ellas haçia la parte del lado derecho tiene arrancado vn pedaço como de dos dedos algo menor de la ternilla de la dicha naris que según me parece y mostro en la dicha parte donde ansi le falta el dicho pedaço fue arrancado con los dientes como se orixina en estos autos (128v)". Salazar fue sentenciado al pago de una multa de cincuenta patacones y dos años de encierro en el temido Presidio de Carare, un 
fuerte militar y campo de trabajos pesados (131r). Esta era una sentencia onerosa que probablemente convertiría a la familia del zapatero en indigentes y que podría llegar a poner en peligro la vida del propio Salazar.

Pocos meses después, Medina retiró su denuncia contra el hombre que ahora llamaba "Juan de Salaçar indio ladino" porque, confesó que "yo fui el que proboque al susso dicho con palabras malsonantes" (132r). Nótese que aquí Medina identifica a Salazar como un indio, no como mestizo, aunque el abogado de Salazar continuó usando la etiqueta racial mixta cuando se refería a su cliente. La sentencia, al final, fue reducida a una multa de veinticinco patacones y un año en Carare, a pesar de los ruegos de su abogado por la liberación de Salazar, cuya esposa estaba postrada en cama y desvalida.

He aquí dos hombres que recurrieron a la violencia en un momento de apasionamiento. Salazar fue denominado mestizo por su agraviado conocido, Medina, así como por los testigos de su acto criminal y las autoridades examinadoras. Pero cuando Medina se calmó lo suficiente, cambió de parecer y llamó a su amigo indio ladino. Medina estaba respondiendo a su relación cambiante con su atacante cuando cambió su descripción de mestizo a indio (Boyer 1998). La amenaza de desfiguración facial, por no mencionar el miedo que debió sentir cuando sangraba en la puerta de la casa del cacique, lo llevó a desairar al zapatero cuando dio a entender su extracción mixta ilegítima -la asociación automática que, en el momento, cualquiera hubiera hecho en respuesta al término "mestizo"-. Sin embargo, una vez Medina estaba seguro de que Salazar no le había hecho daño permanente, estuvo dispuesto a demostrar públicamente su amistad y proximidad étnica, al señalar su pertenencia común a la categoría "indio". A pesar del cambio discursivo del querellante, Salazar siguió siendo "mestizo" a los ojos de la Corona, lo que indica el poder inherente a la papelrealidad: la única clasificación "real" es aquella inscrita en papeles legales por las autoridades apropiadas. El acto de habla del abogado ubicaba a Salazar en una posición poco envidiable en la red social, en comparación con los esfuerzos de acercamiento de Medina.

Me parece crucial distinguir entre las divergentes clasificaciones usadas para identificar a Salazar, por un lado, y por el otro, los grupos sociales que salieron a relucir en el curso de la disputa. ¿Cómo podríamos identificar el grupo de pertenencia de los invitados a la fiesta en la que Salazar le mordió la nariz a Medina? Ciertamente, la celebración tenía un maestro de ceremonias, don Juan, cacique de Fontibón, quien patrocinaba la fiesta. Muchos de sus invitados eran indios, aunque no sabemos a qué "grupo" pertenecían, por cuanto nunca sabemos si los invitados eran tributarios del cacique o si eran de un pueblo vecino. La distinción es importante, ya que la categoría de "indio" no era isomorfa entre las personas nativas presentes en la fiesta: sus identidades primarias eran como fontibones, sogamosos o ubaqueños, los pueblos en los que sostenían relaciones cara a cara. También había indios ladinos, indios hispanohablantes que vivían por fuera del control de los caciques: eran "indios", pero tenían un estatus diferente de los fontibones, quienes eran sujetos del anfitrión de la fiesta. Algunos de los invitados eran llamados mestizos, pero esta no era una fiesta para mestizos explícitamente, y no hay razón para asumir que los juerguistas de extracción mixta llevaban esta denominación a flor de piel mientras bebían su chicha y lentamente entraban en embriaguez. Es probable que los hombres congregados en la casa de don Juan se reconocían unos a otros como artesanos o vecinos.

Probablemente, las autoridades judiciales que juzgaron a Salazar inferían más "grupalidad" entre el zapatero y sus amigos de lo que lo hacían los asistentes a la fiesta, debido a que compartían la desconfianza que la mayoría de los españoles sentían hacia los mestizos. Esto puede explicar que el abogado continuara usando el epíteto "mestizo", incluso después de que Medina se retractó en interés de la amistad. Sin embargo, "indio ladino" era una categoría ambigua que no constituía un grupo en el terreno (Adorno 1991). Con el tiempo, más y más muiscas aprendieron español, de manera que hacia 1650 no era sorprendente encontrar un grupo sustancial de ellos entre los tributarios del cacique de Fontibón, debido a su proximidad con Santafé ${ }^{20}$. Pero también había otros indios ladinos sin ataduras a los caciques, la administración colonial los llamaba "forasteros", personas de otras regiones que vivían en el pueblo y ganaban la vida como jornaleros, capataces y artesanos. Juan de Salazar era uno de estos indios sin ataduras. De hecho, Salazar era una clase particular de forastero: era un 'huauqui', un indio de Quito, un grupo que merecía su propio rótulo, que surge periódicamente en los registros documentales de Santafé21. Muchos huauquis, 
como otros indios ladinos, se identificaban socialmente más con sus pares mestizos que con indios tributarios. Ejercían un cierto nivel de autoridad sobre estos últimos, debido a que frecuentemente estaban atados a intereses poderosos, como hacendados. Bajo estas condiciones, para mí es imposible asegurar con certeza que Medina y Salazar, como indios ladinos, se sentían como miembros de una colectividad de indios, y tampoco puedo afirmar que la heterogénea colección de indios ladinos en Fontibón se hubieran identificado como grupo o que hubieran privilegiado relaciones con otros ladinos por encima de su amistad con mestizos.

Los grupos de pares -algunas veces grupos relativamente estables como los de los tributarios regidos por un cacique, otras veces más fugaces, como los asistentes a la fiesta de Fontibón-se reunían en relaciones que eran, por sí mismas, altamente situacionales. Las personas en la mitad, los mestizos, mulatos e indios ladinos, navegaban el paisaje social plebeyo, pero también estaban sujetos al control de actores más poderosos que podían limitar de forma efectiva cómo se identificaba cada uno, como el abogado que insistía en llamar "mestizo" a Salazar. Por lo tanto, debemos abandonar a Juan de Salazar para enfocarnos en un caso en el que los oponentes estaban a un nivel social más similar, si queremos profundizar nuestro análisis sobre tales dinámicas.

\section{Papelrealidad y mestizaje}

Durante la década de 1570, dos caciques de los repartimientos indígenas de Tibasosa y Turmequé, ubicados cerca de Tunja, generaron miles de páginas de escritos legales para buscar el reconocimiento real de sus derechos sobre sus posiciones de mando. Sus nombres eran Alonso de Silva, quien pretendía el cacicazgo de Tibasosa, y Diego de Torres, pretendiente del cacicazgo de Turmequé. Sus encomenderos -los titulares de las mercedes reales sobre los tributos de sus comunidades- Miguel Holguín (encomendero de Tibasosa) y Pedro de Torres (medio hermano de Diego y encomendero de Turmequé) disputaban los derechos de ambos hombres sobre el cacicazgo sobre la base de su condición de mestizos; los encomenderos apoyaban otros aspirantes que habían servido como regentes antes de que Silva y Torres alcanzaran la edad legal. Al final, el cacicazgo le fue negado a ambos hombres, y se decidió en favor de los regentes, que ya habían ejercido el mando en las dos comunidades ${ }^{22}$.
Torres y Silva eran oponentes férreos del sistema de encomienda y denunciaban los numerosos abusos cometidos por los encomenderos de Tunja, incluyendo las extracciones exageradamente entusiastas de los pagos de tributo en las comunidades nativas, la explotación de la labor indígena, y la falta de instrucción doctrinal efectiva en los pueblos de indios $^{23}$. En la Audiencia de Santafé encontraron aliados, particularmente a Andrés Venero de Leyva, presidente de la Audiencia, y al visitador Juan Bautista de Monzón, ambos estaban enfrascados en una lucha contra los encomenderos de Tunja acerca de la administración de la población indígena (Bonnet 2009; Porro 1995). En otras palabras, había más en la disputa entre los dos caciques mestizos y los encomenderos que simplemente su calidad de mestizos.

Los documentos que conciernen las disputas sobre cacicazgos surgen continuamente en los archivos coloniales de la América española en la estela de la desarticulación de las estructuras políticas precolombinas; no estaba siempre claro quién era el heredero legítimo de un cacicazgo y, en consecuencia, los puestos de mando frecuentemente estaban en disputa ${ }^{24}$. Tales luchas intestinas también generaban aliados para los encomenderos, puesto que había múltiples conflictos de intereses internos en las comunidades nativas. El caso de los caciques de Tibasosa y Turmequé es de especial interés, sin embargo, porque los caciques eran mestizos, una verdad que no fue impugnada por nadie, aunque, precisamente, lo que quería decir "mestizo" para cada una de las partes sí era objeto de desacuerdo. Más aún, ambos hombres también eran participantes activos en la ciudad letrada colonial española, que Ángel Rama imagina en La ciudad letrada como una constelación social, política, legal y administrativa, construida alrededor de ideología de la primacía de la palabra escrita. Don Alonso de Silva, quien pretendía el cacicazgo de Tibasosa, era un secretario notarial en la ciudad capital de Santafé, mientras que don Diego de Torres, el cacique de Turmequé, había sido educado por frailes y había viajado dos veces a Madrid a exponer sus demandas. Contrario a otros caciques, ellos estaban íntimamente involucrados con la producción de la documentación de sus reclamos, debido a que estaban altamente familiarizados con los procesos notariales, así como con los principales tratados filosóficos y teológicos de la era. En otras palabras, las historias de don Alonso de Silva y don Diego de Torres nos proveen una entrada única a la 
forma en que la papelrealidad estaba contectada a la creación de ficciones sociorraciales en el período colonial temprano.

Algunos años atrás, me esforcé por comprender a Diego de Torres a través del prisma de las literaturas indígenas en los Andes. No funcionó. Aunque Torres era, de hecho, el cacique de Turmequé, su vida se desarrolló entre la élite española de Santafé y Tunja, así como en la corte real de Madrid (donde se casó con una mujer española). Torres interviene su persona entre los registros legales de tal manera que borra cualquier pista de alteridad indígena que usualmente enriquece nuestras interpretaciones sobre los textos de autores andinos de la era colonial. Solamente debemos mirar atentamente los mapas de las provincias de Tunja y Santafé hechos por Torres, para notar que no son híbridos de ninguna manera: están basados por completo en convenciones visuales y cartográficas europeas ${ }^{25}$.

He llegado a comprender que mi deseo de retratar a Diego de Torres como un miembro de la ciudad letrada indígena descuidó el aspecto más central de la persona que este cacique proyecta en los documentos: tanto él como Alonso de Silva eran hijos de conquistadores españoles y las hermanas mayores de caciques anteriores (entre los muiscas el cacicazgo se transmitía del tío materno al hijo de la hermana, por medio de un sistema de ascendencia matrilineal). Ser mestizo se ubicaba en el corazón de los reclamos de Torres y Silva por los cacicazgos de Turmequé y Tibasosa. Ninguno negaba su extracción mixta, pero las partes opositoras estaban en desacuerdo sobre cómo debían designarse los individuos mixtos y sobre las implicaciones de ser mestizo.

Ahora me dirijo a la manera en que estos individuos eran identificados como mestizos por sí mismos y por sus oponentes. La clasificación sociorracial ocurre con gran intensidad en los documentos escritos de este tipo, que componen el rastro de papel de estos señores hereditarios: en algunos de los documentos no eran identificados por su calidad (y, por tanto, eran aceptados en el redil español); en otros, eran marcados como mestizos, y por tanto, ilegítimos o idólatras; en otras, podemos observar sus propios modos de autoconstrucción, en los cuales reinterpretan el significado de mestizo como una fuerza cristiana para hacer el bien. En ninguna de estas instancias Torres o Silva esconden su extracción mixta, aunque, como lo demostraré, apelan a esta usando denominaciones diferentes a las de sus enemigos. Lo que deseo mostrar es que Torres, Silva y sus oponentes construyeron las identidades de los dos caciques mestizos por medio del uso de diferentes géneros literario-legales específicos y distintas etiquetas, en consecuencia, nos presentan un caso convincente para argumentar que las clasificaciones raciales se construían mediante apelaciones a la papelrealidad.

Empecemos con los medios sociales en los que don Alonso de Silva pasó la mayor parte de su tiempo entre los estratos de élite en la capital de la Audiencia de Santafé, donde era un asistente de notaría. Cuando encontramos a Silva sentado en su mesa de escribano su linaje mezclado no se menciona, y él es, por tanto, aceptado como persona sin señas - una designación de calidad preferible en una profesión en la que al propio notario se le exigía una designación española pura o de ascendencia española ${ }^{26}$. Tras la muerte de su jefe, Juan de Abiz, hacia 1580, Silva se quedó con sus archivos. Silva pidió ser remunerado con dinero de la herencia de Albiz, por la administración de los papeles notariales. En esos documentos no hay referencia a su condición de mestizo: aquí, es un simple secretario de notaría encargado de una tarea importante ${ }^{27}$. Una década más tarde, Silva fue empleado por Francisco Alava de Villarreal, un notario de la corte, y por un tiempo se le confió la administración de su oficina.

A finales de 1590 estuvo enfrascado en una disputa por algunos papeles que había elaborado cuando estaba encargado de los asuntos de Villarreal; nuevamente, aquí no hay mención de su condición como mestizo, en cambio, se le identifica como secretario, aunque es llamado "don Alonso de Silva", como correspondía a su posición noble, derivado de su estatus como cacique ${ }^{28}$. Incluso cuando fue encarcelado por haber elaborado peticiones infructuosas para varias comunidades nativas que fueron amenazadas con la expulsión de sus territorios, Silva no solo es identificado como carente de marcas sociorraciales, sino que se le menciona con el título de nobleza "don" y reconocido como "vecino" de Santafé, una posición que en ese período solo estaba disponible para españoles y hombres americanos de ascendencia española ${ }^{29}$. En sus transacciones como cliente notarial -cuando incurrió en deudas por la compra de tierras o productos- también se le llama "don"30. En otras palabras, en los intercambios diarios, conducidos sobre la base de la igualdad 
de estatus, los oponentes de Silva dejan de lado su conocimiento sobre su condición de mestizo y, en cambio, lo veían como uno de sus pares.

En contraste, Pedro de Torres y Miguel Holguín, los oponentes de los pretendientes al cacicazgo, ambos encomenderos y vecinos del próspero centro comercial de Tunja, tildan a Silva y a Torres como mestizos en los documentos que produjeron en el curso de su disputa sobre el cacicazgo. En sus acusaciones formales -que les permitían amplia libertad para adornar sus definiciones sobre los mestizos y su clasificación de Diego de Torres y Alonso de Silva como mestizos- y en sus interrogaciones de testigos Torres y Holguín emplean antiguos estereotipos venenosos de los caciques como individuos de nacimiento ilegítimo. Por ejemplo, Diego de Torres es llamado: "mestizo espurio nacido de pugnable e concubito adulterino de hombre casado e de una yndia comun e no descendiente de los ligitimos caciques" 31 . Los dos caciques también son descritos como idólatras: Torres tenía reputación de haber "depojado de ordinario en las dichas borracheras e bayles de los habitos de español que trae e se a vestido e viste mantas de yndios e haze estando en el dicho habito vengan ante el los yndios del dicho repartimiento e los embixa el por su mesma mano en ofensa de dios" ${ }^{\prime 2}$. Estos testimonios no sorprenden en absoluto: se derivan de una plantilla colonial común y cobran su validez porque son etiquetas tan conocidas y porque vienen de las bocas de testigos pudientes-otros encomenderos, obispos, etc. Pero lo que es necesario recordar es que eran altamente eficaces: Torres y Silva perdieron sus apelaciones sobre la base de ser mestizos. Incluso si nunca se referían a sí mismos de esa manera, la papelrealidad ejercida por sus oponentes, con folios tras folios de registros documentales sobre los peligros espirituales y políticos planteados por las personas de sangre mezclada, los convertía, mutatis mutandis, en mestizos ${ }^{33}$.

Pero ambos caciques no solo eran objeto de la papelrealidad. Eran, por sobre todo, percibidos como peligrosos porque eran capaces de realizar actos letrados: eran los sujetos (y no solo los objetos) de la papelrealidad. Pedro de Torres y Miguel de Holguín hacen alusiones directas a los peligros que la comunicación escrita y su control por parte de mestizos plantean a la élite española. Alonso de Silva, el secretario notarial, se ve como un candidato particularmente peligroso para el cargo de cacique "porque es muy demasyado de entendido y letrado para ser caçique de yndios tan chontales e yncapaçes como son los de [Tibasosa]". ${ }^{34}$ Presuntamente, Diego de Torres había escrito cartas a otros caciques en un intento por liderarlos contra los españoles:

Somos ynformados que desde el camino a escrito algunas cartas a los caçiquez de los yndios espeçial al de Bogota yntitulandose que es la cabeça de todos los yndios el señor de las honduras de Turmeque y prometiendoles libertad y otras vanidades entendemos que segun la confiança que en el tienen puesta si a estas partes boluiese se metera en los llanos a donde podria conbocar a todos los yndios y mestizos de este reino ${ }^{35}$.

El mismo acto de escribir, de poner tinta sobre el papel, transgredía una jerarquía social estable, a los ojos de los oponentes de los caciques.

La intertextualidad e intervisualidad de todas estas acusaciones replica la constelación de prácticas letradas, visuales y performativas que componían la ciudad letrada colonial, y nos proveen un retrato más matizado de la papelrealidad hispanoamericana colonial. Esto es particularmente evidente en una acusación errónea hecha contra Diego de Torres, quien, se creía, había estado preparando el robo del sello real en Tunja con una serie de indios y mestizos, causando gran confusión entre las élites de la ciudad:

Se nos acaba de comfirmar la opinion que tenemos de quantas imformaciones falsas se deuen de auer embiado a Vuestra Merced por el liçenciado Monçon y otras personas pues quien en cosa tan façil de aueriguar se atreuio a imformar al contrario de lo que pasa que se puede sospechar de las demas cosas secretas porque como se podra mandar ver por las imformaciones que embiamos ni aqui jamas a asistido cappitan del sello ni emos tenido soldados para su garda ni para otro efecto ni tal nos paso por pensamyento ni el sello se a sacado de las casas reales ni menos de poder del chançiller el qual a tenido siempre la llaue del y solo porque el ayuntamiento de Tunja con grandes ueras nos escriuio como don Diego de Torre mestiço que en 
esos reinos estuuo los años pasados se queria alçar y los indios estauan medio reuelados y tambien çiertos frailes nos auisaron de que se uelasen las çiudades del reino a causa que auria alçamyento y aun desto tuuimos imformacion que ya la emos embiado a Vuestra Merced y de nueuo tornaremos a embiar por este reçelo y por estar el sello en un aposento bajo en el patio de las casas reales le subimos a otro aposento alto en las mismas casas dexando em poder del mismo chançiller las llaues como antes ${ }^{36}$.

En realidad, el sello real nunca estuvo en peligro. Sin embargo, los rumores que circularon en Tunja pusieron en juego la ritualidad del letramiento, y encendió los temores de los encomenderos y de los grandes ${ }^{37}$.

Al principio de este artículo describí la práctica por la que los funcionarios españoles obedecen ceremonialmente un decreto real, al levantar una real cédula y besar el sello real estampado en ella. El sello aparece como algo aparte del documento escrito, sin embargo, era integral para expresar la autoridad suprema del rey: sin el sello, las órdenes del monarca no eran del todo legítimas. Más aún, es la naturaleza visual del sello, el escudo de armas literalmente prensado en el material del documento, antes que las palabras contenidas en él, lo que se reconocía como el transmisor de la autoridad del rey. El oficial que alzó el documento sobre su cabeza y después lo besó estaba, literalmente, ubicándose debajo del rey, quien estaba encarnado en el sello real. Aunque impresa en la superficie de manera mecánica y no milagrosa, la imagen estampada del rey también poseía agencia y podía transformar el estado de cosas políticas y sociales. En la América colonial, un lugar en donde el rey nunca aparecería en persona, esta imagen se convirtió en el eje central de una cadena sintagmática de imágenes religiosas y políticas españolas coloniales (Rappaport y Cummins 2012).

Si el sello real proporcionaba uno de los pivotes alrededor de los cuales giraba la ciudad letrada en las mentes de la élite colonial española, solo podemos adivinar su importancia para los súbditos nativos de Diego de Torres. Para muchos observadores indígenas, especialmente aquellos que vivieron durante el primer siglo tras la invasión española y aquellos que no eran miembros de familias principales, el acto de obedecer un decreto real era uno de los pocos encuentros directos que podían tener con el letramiento alfabético y visual, y su relación con la autoridad máxima. Si podían o no leer los documentos en cuestión es inmaterial, porque los decretos reales eran inspeccionados por los participantes en la ceremonia y después leídos en voz alta (en español) a los espectadores. Más importante, aunque no siempre pudieron haber expresado el contenido del decreto en cuestión, tales compromisos con la imagen y la escritura impartían un sistema de valores ligado al letramiento y el lenguaje. Si vemos el sello como el rastro dejado por una actividad, en oposición a la firma de un individuo (en este caso, el rey), como un espacio gráfico ceremonial que reemplazaba un espacio físico ceremonial, las formas en que los habitantes nativos podrían haber interpretado el consentimiento ritual de un decreto se vuelve más comprensible (Fraenkel 1992). En este sentido, sería mejor interpretar el reconocimiento del sello real como la intersección entre formas de conmensurabilidad indígenas y españolas, que operaban en una analogía basada en prácticas rituales, y así creaban un espacio en que estas acciones y marcas se podían interpretar mutuamente.

Por tanto, don Diego de Torres y don Alonso de Silva no solo eran los objetos de la papelrealidad colonial, sino que eran participantes activos del régimen literario. Sus respuestas a las acusaciones de sus oponentes demuestran la forma en que las argumentaciones legales transgreden las clasificaciones usuales de calidad. Esto es evidente en la conexión que Diego de Torres traza entre ser mestizo y su capacidad para gobernar Turmequé. Aun sin clasificarse evidentemente como mestizo, escribe: "Entenderian que por ser hijo de español y crisptiano los dichos vuestro presidente y oydores me quitan el dicho mi caçicazgo y que me uviera valido mas ser hijo de yndio ydolatra y no de crisptiano entendiendo ellos que en ser hijo de español y crisptiano como lo soy abia de ser mejor anparado por ser de tan buena sangre proçedida de españoles y crisptianos por lo qual todos los caciques deste rreyno me quieren y aman" ${ }^{38}$. Esta es una clara declaración de que el mestizaje era un proceso por medio del cual la sangre española "redimía" la sangre indígena. También expresa el agudo sentido de Torres sobre el alcance de su poder: la referencia sobre el amor al final del fragmento debe ser interpretada en 
el contexto político colonial, en el que el amor significaba lealtad hacia un soberano, no la emoción romántica que hoy en día llamamos amor ${ }^{39}$. En la opinión de Torres, los caciques vecinos le demostraban amor debido a la abrumadora legitimidad y potencia de su sangre.

Entonces, Torres y Silva no perciben como contradictorio que fueran, a un tiempo, los vástagos de linajes españoles nobles y que al mismo tiempo ocuparan posiciones de mando en sus comunidades nativas. Cuando Torres, al firmar su nombre en los documentos, añade la palabra "cacique", no está diciendo que sea un indio, sino un cristiano noble. Está ejecutando su estatus mediante su propia firma.

\section{Conclusiones}

La papelrealidad necesita tinta y papel, sin embargo, escribir es solo una dentro de una constelación de prácticas que se intersectan y que, aunadas, crean un ethos letrado en la América española colonial y le confiere eficacia al letramiento en el mundo real. Más aún, escribir es solo uno de los espacios en los que los individuos se clasificaban como pertenecientes a una categoría sociorracial particular dentro de la formación social colonial. En ocasiones designados como mestizos, en otras ocasiones como hijos de españoles, Diego de Torres y Alonso de Silva encuentran aliados en la administración colonial, particularmente, en los oficiales nombrados por la Corona para administrar las provincias de Santafé y Tunja. Sus enemigos eran los encomenderos de Tunja. La imbricada constelación de géneros literarios no solo incluían las transcripciones de sus disputas con los encomenderos, sino también las otras formas de escritura en que los caciques no son clasificados (misivas, contratos, documentos notariales y las firmas que acompañan todos estos); las ejecuciones públicas que señalaban su estatus (dar testimonios orales y recogerlo de testigos); y las imágenes de la élite española alojada en sus memorias (textos literarios, descripciones fisionómicas). La interacción de estos géneros diferentes alimentó la disputa sobre los derechos de Torres y Silva sobre sus cacicazgos. Los géneros se delineaban de forma distinta por los diferentes participantes de la disputa y sus aliados. Esto, para mí, muestra cómo operaban el letramiento y la papelrealidad en la América española colonial.
El proceso de identificación sociorracial estaba íntimamente asociado con el ejercicio de la papelrealidad: el tejido de verdades legales salidas de la urdimbre y la trama de interacciones sociales y la búsqueda de intereses en situaciones concretas, no la legitimación de clasificaciones preexistentes visibles para todos, ni la rectificación de categorizaciones "incorrectas" de individuos. Más aún, la creación de estas ficciones legales era histórica y culturalmente específica; no era lo mismo que las designaciones de castas del siglo XVIII o adscripciones raciales en el período moderno. Esta emergió de una constelación particular de prácticas de letramiento, bastante específicas para la era colonial.

En nuestro afán por imponer nuestras sensibilidades raciales modernas sobre actores de otros períodos cronológicos, tendemos a perder de vista que la raza como la conocemos hoy en día es una construcción moderna completamente ajena a la temprana modernidad. No podemos atribuir nuestros propios métodos para identificar individuos según un régimen visual de color al período colonial, cuando las clasificaciones de las personas según calidad eran mucho más fluidas y estaban atadas a nociones diferentes que distinguían un individuo de otro y a la manera en que este proceso de categorización estaba destinado a desarrollarse. Necesitamos transgredir la raza, resituarla en la visión de mundo colonial y en la práctica de la papelrealidad, si queremos encontrar un sentido a las acciones del visitador colonial en Sogamoso, Lázaro Mulato, Juana Galván, Juan de Salazar, don Alonso de Silva y don Diego de Torres.

\section{Agradecimientos}

La investigación de archivo que posibilitó este artículo fue financiada por la Escuela de Posgrados de Georgetown University (2005), la Wenner-Gren Foundation for Anthropological Research (20052006) y una beca Fulbright (2007). Agradezco a Tom Cummins por su interlocución tan productiva durante tantos años. La idea de este artículo surgió de una invitación que me hizo Harvey Graff, de Ohio State University, para que presentara una conferencia en la primavera de 2013 sobre la intersección del letramiento y el proceso de mestizaje. Mis profundos agradecimientos a Verónica Zacipa por sus labores en traducir tan elegantemente mi inglés a un español educado. 


\section{Referencias Citadas}

Acevedo Latorre, Eduardo

1971 Atlas de los mapas antiguos de Colombia. Bogotá: Litografía Arco.

Adorno, Rolena

1991 "Images of Indios Ladinos in Early Colonial Peru", en Kenneth J. Andrien y Rolena Adorno, eds., Transatlantic Encounters: Europeans and Andeans in the Sixteenth Century, 232-270. Berkeley: University of California Press.

Arzáns de Orsúa y Vela, Bartolomé

1965 Historia de la villa imperial de Potosí. Providence: Brown University Press.

Aubert, Guillaume

2004 "'The Blood of France': Race and Purity of Blood in the French Atlantic World", The William and Mary Quarterly 61, 4: 439-478.

Baber, R. Jovita

2009 "Categories, Self-Representation and the Construction of the Indios", Journal of Spanish Cultural Studies 10, 1: 27-41.

Bonil Gómez, Katherine

2011 Gobierno y calidad en el orden colonial: Las categorías del mestizaje en la provincia de Mariquita en la segunda mitad del siglo XVIII. Bogotá: Ediciones Uniandes.

Bonnet Vélez, Diana

2009 "Entre el interés personal y el establecimiento colonial: Factores de confrontación y de conflicto en el Nuevo Reino de Granada entre 1538 y 1570", Historia Crítica, Edición especial de 2009: 52-67.

Boyer, Richard

1998 "Respect and Identity: Horizontal and Vertical Reference Points in Speech Acts", The Americas 54, 4: 491-509.

Brubaker, Rodgers y Frederick Cooper

2000 "Beyond 'Identity", Theory and Society 29: 1-47.

Burshatin, Israel

1996 "Elena alias Eleno: Genders, Sexualities, and 'Race' in the Mirror of Natural History in Sixteenth-Century Spain", en Sabrina Petra Ramet, ed., Gender Reversals and Gender Cultures: Anthropological and Historical Perspectives, 105-122. London: Routledge.

Cañeque, Alejandro

"The Emotions of Power: Love, Anger and Fear, Or How To Rule the Spanish Empire", en Sonya Lipsett-Rivera y Javier Villa-Flores, eds., Colonial Emotions: Affective Economies and Colonial Domination in New Spain. Albuquerque: University of New Mexico Press, en prensa.

Carrera, Magali,

2003 Imagining Identity in New Spain: Race, Lineage, and the Colonial Body in Portraiture and Casta Paintings. Austin: University of Texas Press.

Cobo Betancourt, Juan Fernando,

2012 Mestizos heraldos de Dios: La ordenación de sacerdotes descendientes de españoles e indígenas en el Nuevo Reino de Granada y la racialización de la diferencia 1575-1590. Bogotá: Instituto Colombiano de Antropología e Historia.

Cope, R. Douglas

1994 The Limits of Racial Domination: Plebeian Society in Colonial Mexico City, 1660-1720. Madison: University of Wisconsin Press.

Covarrubias Orozco

1995 [1611] Sebastián de, Tesoro de la lengua castellana o española. Madrid: Castalia.
Dery, David

1998 "'Papereality' and Learning in Bureaucratic Organizations", Administration \& Society 29, 6: 677-689.

Feerick, Jean E.

2010 Strangers in Blood: Relocating Race in the Renaissance. Toronto: University of Toronto Press.

Fraenkel, Béatrice

1992 La signature: Genèse d'un signe. Paris: Gallimard.

Friede, Juan, ed.

1976 Fuentes documentales para la historia del Nuevo Reino de Granada desde la instalación de la Real Audiencia en Santafé. Bogotá: Biblioteca Banco Popular, 8 vols.

Garrido, Margarita

2005 "'Free Men of All Colors' in New Granada", en Nils Jacobsen y Cristóbal Aljovín de Losada, eds., Political Cultures in the Andes 1750-1950, 164-183. Durham: Duke University Press.

González Holguín, Diego

1989 [1608] Vocabulario de la lengua general de todo el Peru llamada lengua qquichua o del inca. Lima: Editorial de la Universidad Nacional Mayor de San Marcos.

Groebner, Valentin

2007 Who Are You? Identification, Deception, and Surveillance in Early Modern Europe. New York: Zone Books.

Guevara-Gil, Armando y Frank Salomon

1994 “A 'Personal Visit': Colonial Political Ritual and the Making of Indians in the Andes", Colonial Latin American Review 3, 1-2: 3-36.

Hering Torres, Max S

2011 "Limpieza de sangre en España: Un modelo de interpretación", en Nikolaus Böttcher, Bernd Hausberger y Max S. Hering Torres, eds., El peso de la sangre: Limpios, mestizos y nobles en el mundo hispánico, 29-62. México DF: El Colegio de México.

Herrera Ángel, Marta

2002 Ordenar para controlar: Ordenamiento espacial y control político en las llanuras del Caribe y en los Andes centrales neogranadinos, siglo XVIII. Bogotá: Instituto Colombiano de Antropología e Historia/Academia Colombiana de Historia.

1996 Poder local, población y ordenamiento territorial en la Nueva Granada - siglo XVIII. Bogotá: Archivo General de la Nación.

Herzog, Tamar

2003 Defining Nations: Immigrants and Citizens in Early Modern Spain and Spanish America. New Haven: Yale University Press.

2005 "Early Modern Spanish Citizenship: Inclusion and Exclusion in the Old and the New World", en John Smolenski y Thomas J. Humphrey, eds., New World Orders: Violence, Sanction, and Authority in the Colonial Americas, 205-25. Philadelphia: University of Pennsylvania Press.

Hull, Matthew

2012 Government of Paper: The Materiality of Bureaucracy in Urban Pakistan. Berkeley: University of California Press.

Jaramillo Uribe, Jaime

1968 Ensayos sobre historia social colombiana. Bogotá: Editorial Universidad Nacional de Colombia.

Katzew, Ilona

2004 Casta Painting: Images of Race in Eighteenth-Century Mexico. New Haven: Yale University Press. 
Lee López, R.P. Fray Alberto

1962 Clero indígena en el Arzobispado de Santa Fé en el siglo XVI. Bogotá: Editorial Kelly.

López, Mercedes

"La memoria de las imágenes: Donantes indígenas en el lienzo de ánimas de San Nicolás de Tolentino", en AA.VV., Historia \& imágenes: Los agustinos en Colombia, 400 años, 29-39. Bogotá: Museo Nacional, sin fecha.

Majluf, Natalia, ed.

2000 Los cuadros de mestizaje del Virrey Amat. Lima: Museo de Arte de Lima.

Olaechea, Juan Bautista

1992 El mestizaje como gesta. Madrid: Colecciones Mapfre.

O'Toole, Rachel

2012 Bound Lives: Africans, Indians, and the Making of Race in Colonial Peru. Pittsburgh: University of Pittsburgh Press.

Perry, Mary Elizabeth

1999 "From Convent to Battlefield: Cross-Dressing and Gendering the Self in the New World of Imperial Spain", en Michèle Aina Barale, Jonathan Goldberg, Michael Moon, y Eve Kosofsky Sedgwick, eds., Queer Iberia: Sexualities, Cultures, and Crossings from the Middle Ages to the Renaissance, 394-419. Durham: Duke University Press.

Poma de Ayala, Felipe Guaman

1980 [1615] El primer nueva corónica y buen gobierno. John Murra y Rolena Adorno, eds. Mexico: Siglo XXI.

Porro Gutiérrez, Jesús María

1995 Venero de Leiva: Gobernador y primer presidente de la Audiencia del Nuevo Reino de Granada. Valladolid: Secretariado de Publicaciones, Universidad de Valladolid.

Rahman, Bhavani

2012 Document Raj: Writing and Scribes in Early Colonial South India. Chicago: University of Chicago Press.

Rama, Angel

2004 La ciudad letrada. Hanover, N.H.: Ediciones del Norte.

Rappaport, Joanne

2012 “'Asi lo paresçe por su aspeto': Fisiognomía y construcción de la diferencia en la Bogotá colonial”, Tabula Rasa 17: 13-42.

2012 "Buena sangre y hábitos españoles: Repensando a Alonso de Silva y Diego de Torres", Anuario Colombiano de Historia Social y de la Cultura 39, 1: 19-48.

2012 "El mestizo que desaparece: El género en la construcción de redes sociales entre mestizos de élite en Santafé de Bogotá, siglos XVI y XVII", en Juan Camilo Escobar Villegas, Sarah de Mojica, y Adolfo León Maya, eds., Celebraciones y crisis: Procesos independentistas en Iberoamérica y la Nueva Granada, pp. 365-86. Bogotá: Editorial Pontificia Universidad Javeriana.
2009 "Mischievous Lovers, Hidden Moors, and Cross-Dressers: Passing in Colonial Bogotá", Journal of Spanish Cultural Studies 10, 1: 7-25.

2014 The Disappearing Mestizo: Configuring Difference in the Colonial Andes. Durham: Duke University Press.

Tom Cummins

2012 Beyond the Lettered City: Indigenous Literacies in the Andes. Durham: Duke University Press.

2005 República de Colombia, Censo general 2005. Bogotá: Departamento Administrativo Nacional de Estadísticas.

Rojas, Ulises

1965 El cacique de Turmequé y su época. Tunja: Imprenta Departamental de Boyacá.

Schwartz, Stuart, y Frank Salomon

1999 "New Peoples and New Kinds of People: Adaptation, Readjustment, and Ethnogenesis in South American Indigenous Societies (Colonial Era)", en Frank Salomon y Stuart B. Schwartz, eds., The Cambridge History of the Native Peoples of the Americas, vol. 3: South America, part 2, 443-501. Cambridge: Cambridge University Press.

Seed, Patricia

1995 Ceremonies of possession in Europe's conquest of the New World, 1492-1640. Cambridge: Cambridge University Press.

Seth, Vanita

2010 Europe's Indians: Producing Racial Difference, 15001900. Durham: Duke University Press.

Solórzano Pereira, Juan de

1736 Política indiana. Madrid: Matheo Sacristan.

Zúñiga, Jean-Paul

1999 "La voix du sang: Du métis à l'idée de métissage en Amérique espagnole", Annales HSS 54, 2: 425-452.

\section{Archivos y fuentes primarias}

Archivo General de la Nación (AGN/B)

Caciques e Indios 11, doc. 6, 331v; 24, doc. 2, 124-147; 25, d. 2, 30r-44v; 61, d. 3, 214v.

Empleados Públicos de Cundinamarca 11, 528-549; 29, 394-411.

Encomiendas 21, d. 9, 404r.

Juicios Criminales 93, d. 12, 902r-906v; 97, d.17.

Miscelánea de la Colonia 8, d. 18, 609v; 8, d. 18, 658r.

Notaría 1, tomo la, 88v.

Visitas de Cundinamarca, tomo 1, no 5, 813r.

Archivo General de Indias (AGI/S),

Contratación 5230, n.5, r.26.

Mapas y Planos, Panamá 7; 8

Patronato 196, r. 16.

Santa Fe 16, r.21, n.76-1, 3r; 16, r.26, n.169, 1r-v.

Archivio Generale della Compagnia di Gesù, Roma (AGCG/R) Novi Regni et Quitensis, Historia 12-I, 68v-69r.

\section{Notas}

1 "Descripción de los yndios de Cucunubá y Bogotá", 1580, Archivo General de la Nación (AGN/B), Visitas de Cundinamarca, tomo 1, no 5, 813r. Nótese que cuando uso la palabra "indio" me refiero a la categoría colonial, me abstendré de usar términos racializados en otras instancias.
2 Nótese que no he encontrado una traducción adecuada para la palabra "literacy" y he optado por el neologismo "letramiento", como una explicación del proceso de interpretar formas de inscripción alfabéticas y visuales. El equivalente castellano tradicional, "alfabetización", pone en primer plano la escritura alfabética sobre otras formas 
de inscripción y ejecución. Por supuesto, "letramiento" también tiene la escritura alfabética, o "letras", como raíz y, por tanto, constituye una explicación imperfecta del proceso que intento describir.

3 Aunque, en el Imperio Español, una muy pequeña cantidad de ocasiones el género de un individuo era cuestionado (como describe Burshatin en "Elena alias Eleno") o era alterado mediante una petición legal (según Perry. "From Convent to Battlefield"), no he encontrado tal caso en el Nuevo Reino de Granada. En los registros históricos hay muchos ejemplos de tributarios que vivían en pueblos diferentes de aquellos en los que estaban registrados (Herrera Ángel, Poder local, 79-86). En estos casos, la papelrealidad de la visita debía reconciliarse con otros documentos, generalmente, mediante testimonios orales.

4 Seth, Europe's Indians, cap. 4. Por falta de un vocablo más preciso, en este artículo uso la palabra "raza", pero invito al lector a comprenderla en su manifestación colonial. El término colonial de "raza" no se aplicaba a las categorías de "indio", "mestizo", etc., sino que se refería más propiamente al linaje aristocrático, para distinguirlos de aquellos con sangre cristiana "pura" de los descendientes de conversos judíos e islámicos o de los descendientes de herejes; Hering Torres, "Limpieza de sangre en España". Este fue un período en que los atributos sociales importantes, incluyendo la familia, el honor y la religión, empezaron a ser pensados como algo que se "llevaba en la sangre". Las personas de los siglos XVI y XVII se ocupaban de la transmisión de pureza espiritual -la virtud- por medio de relaciones de sangre, no en la transmisión de características genéticas; Zúñiga, "La voix du sang". Así, al igual que la limpieza de sangre, las nociones de raza y pureza racial tenían como punto de partida consideraciones genealógicas.

5 Los casos de personas que pasan por una calidad diferente a aquella con que nacen (racial passing) en el sentido moderno eran escasos. En la Santafé colonial había una mayor preocupación por los conversos judíos e islámicos que se hacían pasar por "antiguos cristianos", como personas cuya genealogía era totalmente cristiana; Rapaport, "Mischievous Lovers, Hidden Moors, and Cross-Dressers".

$6 \quad$ No hay cuadros de castas en el Nuevo Reino de Granada (solo hay un grupo en Perú, documentado por Majluf, Los cuadros de mestizaje del Virrey Amat). Además, debemos abstenernos de cometer el error de comprimir los tres siglos del período colonial en un solo conjunto de usos y costumbres estables. En el período colonial temprano, "casta" refiere a un linaje, no una categoría sociorracial en el sentido moderno de la palabra; Covarrubias, Tesoro de la lengua castellana o española, 282). El término solo comienza a aparecer, en el sentido de jerarquía sociorracial, en el siglo XVIII, e incluso entonces, no se cristaliza tan coherentemente en el sistema como ocurrió en México (entre muchos otros autores, Cope, The Limits of Racial Domination), porque en Nueva Granada hubo tanta mezcla que era difícil identificar a los individuos según su casta. Más aún, mientras en el siglo XVIII había individuos identificados como "blancos", esta no era una categoría en el período colonial temprano. Las categorías de casta ciertamente aparecen en los documentos coloniales tardíos, pero coexisten allí con un sistema de clasificación por estatus legal o color, así que los individuos se identificaban según si estaban exentos o no de pagar tributo o servitud, y otras obligaciones similares, y de acuerdo a si eran o no "blancos": aquellos que eran libres y no blancos eran "libres de todos los colores", una terminología que no existía en el período colonial temprano. La documentación colonial tardía producida en las áreas rurales tiende a evitar por completo, por lo menos en expedientes de asuntos civiles, la clasificación intermedia de "mestizo" y sus diferentes permutaciones, prefiere simplemente identificar aquellos que no son indios, españoles o negros, como "vecinos". Ver Bonil Gómez, Gobierno y calidad en el orden colonial; Garrido, "Free Men of All Colors' in New Granada"; Herrera Ángel, Ordenar para controlar; Jaramillo Uribe, Ensayos sobre historia social colombiana.

7 Compárese con la definición que da Covarrubias a "elefante", a la que le dedica siete páginas; ibid., 451-457.

8 Sobre cómo términos como "indio" también operaban como ubicaciones legales en el período colonial, ver O’Toole, Bound Lives, cap. 3. No estoy interesada en la voluminosa legislación que emergió durante el transcurso del período colonial para codificar los derechos y obligaciones de los miembros de las variadas categorías, debido a que estas leyes fueron aplicadas de forma desigual en el tiempo y el espacio; esto es muy aparente, por ejemplo, en la aplicación de las leyes concernientes a la ordenación de sacerdotes mestizos, como ha sido estudiado por Olaechea, El mestizaje como gesta, en el contexto imperial, y por Cobo Betancourt, Mestizos heraldos de Dios y Lee López, Clero indígena en el Arzobispado de Santa Fé en el siglo XVI para el Nuevo Reino de Granada. Por esta razón, he optado por enfocarme en las prácticas clasificatorias en la práctica, en lugar de la ley imperial.

9 Sobre encuentros violentos entre las nacionalidades ibéricas en Potosí, Bolivia, ver Arzáns de Orsúa y Vela, Historia de la villa imperial de Potosí.

10 Esto continúa así hasta el presente, cuando la categoría de mestizo ni siquiera aparece en el censo nacional colombiano, que cataloga los miembros de los grupos étnicos, incluyendo indígenas, rom (Roma), raizal (nativos de las islas anglohablantes caribeñas de San Andrés y Providencia), palenquero (descendientes de comunidades cimarronas), negro, mulato y afrodescendiente; los mestizos y blancos son clasificados como "ninguna de las anteriores". Ver República de Colombia, Censo general 2005, 132-133, 188-193.

11 Reproducción digital del cuadro: <http://www.banrepcultural.org/durero/sites/default/files/sites/default/files/8.jpg >. Una excelente exégesis de esta imagen se puede encontrar en López, "La memoria de las imágenes". También me he beneficiado de extensas discusiones con López acerca de los individuos incluidos en este cuadro.

12 Reproducción digital: $<$ https://www.google.com/search?q=sutata usa+cacique \&client=firefox-a\&hs=jM3\&rls=org.mozilla:en-US :official \&channel=fflb\&source $=$ lnms\&tbm $=$ isch\&sa $=X \&$ ei $=$ NGEcVJGgG8ejyASC_4LoAQ\&ved=0CAkQ_AUoAg\&biw $=1436 \& b i h=1255 \#$ facrc=_\&imgdii=_\&imgrc=pPLLyLUbOH DjUM\%253A\%3BjJud_cpFPoXkpM\%3Bhttps\%253A\%252F $\% 252 \mathrm{Fc} 1$. staticflickr.com\%252F3\%252F2727\%252F4031190 266_8514991980_z.jpg\%3Bhttps\%253A\%252F\%252Fwww. flickr.com\%252Fphotos\%252Fmiseryka\%252F4031190266 $\% 252 \mathrm{~F} \% 3 \mathrm{~B} 360 \% 3 \mathrm{~B} 640>$.

13 Mercedes López, comunicación personal.

14 "Don Juan, cacique de los indios de Cucunubá [sic], defensa de su cacicazgo" 1607-1620, AGN/B, Caciques e Indios 11, doc. 6, 
331v. Nótese que Cunucubá, cerca de Vélez, y Cucunubá, cerca de Santafé, son dos comunidades distintas. Este documento se refiere al pueblo cerca de Vélez. Nótese, también, que la palabra "color" era femenina en el período colonial.

15 "Expediente de información y licencia de pasajero de indias a Gonzalo García Zorro, canónigo de la catedral de Santa Fe, con sus criados Luis de Chaves y Juan Morillo, al Nuevo Reino de Granada", 1589, Archivo General de Indias (AGI/S), Contratación 5230, n.5, r.26. "Apuntar", en este caso, se refiere a que su barba era tenue (en otros documentos denotaría que la barba apenas empezaba a salir, pero García Zorro tenía más de cuarenta años cuando este certificado fue compuesto). Sobre la terminología de los colores, ver Rappaport, "Asi lo paresçe por su aspeto".

16 "Descripción de los indios de Chocontá", 1639, AGN/B, Miscelánea de la Colonia 8, d. 18, 658r.

17 "El protector de indígenas contra Francisco de Vargas Figueroa, encomendero de los aborígenes de Chitaraquem, por haber incluido éste en el censo de indígenas, a Juana Galbán y sus hijos", 1642, AGN/B, Juicios Criminales 97, d.17.

18 "Salazar, Juan, mestizo, zapatero, causa que se le siguió por haber desnarigado de un mordisco a Juan Medina, indio de Fontibón”, 1650-1651, AGN/B, Caciques e Indios 24, doc. 2, 124-147. Todas las citas siguientes de este documento estarán entre paréntesis.

19 De acuerdo con Diego González Holguín, Vocabulario de la lengua general de todo el Peru llamada lengua qquichua o del inca, en quechua, "yaya" se puede traducir como "padre, amo, señor". El apodo hacía burla de Salazar porque, en broma, se refería a él como un hombre de alto rango mientras que reconocía su origen quiteño.

20 El observador jesuita Gonzalo de Lira informa que muchos indios urbanos "son por la maior parte tan ladinos que avorrecen su lengua y ablan siempre en castellano". "Letras annuas de la Prouinçia del Nueuo Reyno del año de 1611 y 612”, 1611-12, Archivio Generale della Compagnia di Gesù, Roma (AGCG/R), Novi Regni et Quitensis, Historia 12-I, 68v-69r. Veinte años antes del encarcelamiento de Salazar, la visita a Chocontá contiene testimonio de que, en efecto, la mayoría de los indios hablaban español. "Descripción de los indios de Chocontá", 1639, AGN/B, Miscelánea de la Colonia 8, d. 18, 609v.

21 Huanqui significa "hermano" en quichua. Véase "Causa seguida a Francisco Suarez, en virtud de denuncio de Juan Acero de Vargas, de haber seducido y desflorado a Catalina Acero de Vargas, su hermana", 1667, AGN/B, Juicios Criminales 93, d. 12, 902r-906v.

22 Ver, Rappaport, "Buena sangre y hábitos españoles". Nótese que las acusaciones sobre ser mestizo no tenían nada que ver con su apariencia. Los documentos de este período describen a Torres como "un hombre de buen cuerpo, no muy alto, un poco visco de los ojos y de pocas barbas" -esto quiere decir que no había nada particularmente "mestizo" de su descripción; Rojas, El cacique de Turmequé y su época, 192.

23 "Relación sobre el buen gobierno del Nuevo Reino de Granada", 1584, AGI/S, Patronato 196, r. 16; ha sido publicada en numerosas versiones, incluyendo a Friede, Fuentes documentales para la historia del Nuevo Reino de Granada desde la instalación de la Real Audiencia en Santafé, VIII, 236-274 y Rojas, El cacique, 67-69.

24 Es imposible cuantificar cada cuánto ocurría que los caciques fueran acusados de ser mestizos, puesto que la preservación de estos documentos en los archivos coloniales es casi accidental.
Generalmente, tanto los oponentes como quienes pretendían los títulos de cacicazgo venían de las propias comunidades indígenas: las peleas entre linajes indígenas eran más frecuentes que las contiendas por un cacicazgo entre indios y mestizos. Aparte de estas demandas -la mayoría de las cuales no tenían nada que ver con asuntos sociorraciales, sino que dependían del descenso de caciques previos-, he encontrado muy pocas decisiones legales concernientes a la asignación de mestizos en posiciones de autoridad en la administración colonial.

25 Torres produjo los primeros mapas que sabemos de Colombia "Plano de la Provincia de Tunja, sus pueblos y jurisdicción", 1584, AGI/S, Mapas y Planos, Panamá 7, y "Plano de la Provincia de Santa Fe, sus pueblos y términos", 1584, AGI/S, Mapas y Planos, Panamá 8; las mejores reproducciones de estos mapas se pueden encontrar en Eduardo Acevedo Latorre, Atlas de los mapas antiguos de Colombia, 45-46).

26 En Política indiana, Solórzano expone que los mestizos nacidos dentro del matrimonio eran elegibles para estos puestos, pero aquellos nacidos de relaciones adúlteras -quienes, como observa cortantemente, eran la mayoría de los mestizos- no eran elegibles; lib 2, cap. 30, arts. 20-21.

27 "Albiz Juan de, fallecido en el desempeño de la secretaria de camara. Demanda de Alonso de Silva, por sus honorarios, del tiempo que tuvo bajo su cuidado los papeles del extinto secretario", 1582, AGN/B, Empleados Públicos de Cundinamarca 29, 394-411.

28 "Alvarez de Villarreal, Francisco, escribano de camara, demanda que le pusiera Juana de Olalla, hija natural del capitan Anton de Olalla, por refundicion de documentos, del pleito que ella adelantara con los herederos legitimos del susodicho capitan", 1598, AGN/B, Empleados Publicos de Cundinamarca 11, 528-549.

29 "Indios de Guatavita: Piden no ser trasladados", 1593, AGN/B, Caciques e Indios 25, d. 2, 30r-44v. Ver, Herzog, "Early Modern Spanish Citizenship".

30 Por ejemplo, "Obligación. Alonso de Silva debe a Luis Gutiérrez y a Rodrigo Gutiérrez, mercaderes, 150 pesos de oro de 20 quilates por la compra de telas", 1584, AGN/B, Notaría 1 , tomo $1^{\mathrm{a}}, 88 \mathrm{v}$.

31 "Don Diego de Torres, caciques, capitanes e indios de Turmequé contra Pedro de Torres su encomendero, sobre delitos", 1574-75, AGN/B, Encomiendas 21, d. 9, 404r.

32 Ibid.

33 Juan Fernando Cobo Betancourt, Mestizos, heraldos de Dios, cap. 3 argumenta esta cuestión muy persuasivamente en relación con el sacerdote mestizo P. Gonzalo García Zorro.

34 "Cacicazgo de Tibasosa: Títulos de Alonso de Silva en la sucesión en dicho cacicazgo; su pleito con Miguel Holguín, encomendero, quien se oponía a esa sucesión”, 1571-76, AGN/B, CI 61, d. 3, 214v.

35 "Carta de Francisco Auncibay y Bohórquez, oidor de la Audiencia de Santa Fe (10/2/1577)", AGI/S, Santa Fe 16, r.21, n.76-1, 3r.

36 "Carta de la Audiencia de Santa Fe", AGI/S, Santa Fe 16, r.26, n.169, 1r-v.

37 Es dudoso que realmente hubiera planes de una rebelión indígena-mestiza en marcha, aunque los extensos contactos que Torres y Silva tenían con la mayoría de los caciques poderosos del altiplano se fundamentan en la lista de testigos que testificaron a su favor.

$38 \mathrm{AGN} / \mathrm{B}$, Encomiendas 21, 409r.

39 Cañeque, "The Emotions of Power", En prensa. 